\title{
MINERAL RESOURCE POTENTIAL OF THE SPANISH PEAKS WILDERNESS STUDY AREA, HUERF ANO AND LAS ANIMAS COUNTIES, COLORADO
}

\author{
By \\ Karin E. Budding, U.S. Geological Survey \\ and \\ Steven E. Kluender, U.S. Bureau of Mines
}

\section{STUDIES RELATED TO WILDERNESS}

Under the provisions of the Wilderness Act (Public Law 88-577, September 3, 1964) and related acts, the U.S. Geological Survey and the U.S. Bureau of Mines have been conducting mineral surveys of wilderness and primitive areas. Areas officially designated as "wilderness," "wild," or "canoe" when the act was passed were incorporated into the National Wilderness Preservation System, and some of them are presently being studied. The act provided that areas under consideration for wilderness designation should be studied for suitability for incorporation into the Wilderness System. The mineral surveys constitute one aspect of the suitability studies. The act directs that the results of such surveys are to be made available to the public and be submitted to the President and the Congress. This report discusses the results of a mineral survey of the Spanish Peaks Wilderness Study Area, San Isabel National Forest, Huerfano and Las Animas Counties, Colo. The area was established as a wilderness study area by Public Law 96-560, December 22, 1980.

\section{MINERAL RESOURCE POTENTIAL SUMMARY STATEMENT}

A geologic and geochemical investigation and a survey of mines and prospects have been conducted to evaluate the mineral resource potential of the Spanish Peaks Wilderness Study Area, Huerfano and Las Animas Counties, in south-central Colorado. The study area is underlain by sedimentary rocks of Paleozoic to Tertiary age (Johnson, 1969). Stocks and dikes were emplaced between 20 and 25 m.y. ago (Smith, 1979) forming East and West Spanish Peaks and the White Peaks.

Most of the study area lacks significant geochemical anomalies and has a low mineral potential. Anomalous concentrations of gold, silver, copper, lead, and zinc in the rocks and drainage basins in the vicinity of the old mines and prospects on West Spanish Peak indicate a moderate potential for small mineralized veins in this area. Ore-bearing veinlets have been worked in the past, primarily for silver and lead; however, the sparsity, small size, and low grade of the veins diminish their significance.

The depth of several thousand feet at which coal may underlie the surface rocks of the study area makes it a resource with little likelihood of development. The potential for oil and gas appears low because of the apparent lack of structural traps and the intense igneous activity in the area.

\section{INTRODUCTION}

The Spanish Peaks Wilderness Study Area covers about 19,570 acres of the San Isabel National Forest in south-central Colorado (fig. 1). The study area is in the westernmost part of the Great Plains, bordering the eastern foothills of the Sangre de Cristo Mountains. Elevations range from $13,626 \mathrm{ft}$ on the summit of West Spanish Peak to about $8,400 \mathrm{ft}$ in the western part, near Cuchara. The east half of the study area is characterized by rugged terrain in which the land and drainages slope radially away from East and West Spanish Peaks. The principal drainages are Wahatoya and Trujillo Creeks. In the west half of the study area, the terrain is less severe. The major drainages are the north-flowing Chaparral and Echo Creeks. North, Middle, and South White Peaks (elevation 10,446 ft) are near the west boundary of the study area.

Colorado Highway 12 and the Cucharas River parallel the study area on the west. U.S. Forest Service Route 415 and the Apishapa River parallel the southern margin. Secondary roads are sparsely located near the boundary of the study area.

Details of the geology of the study area (Budding and Lawrence, 1983b) and the results of the geochemical survey (Budding and Lawrence, 1983a) are presented as separate maps of the Spanish Peaks Wilderness Study Area. Only the aspects of the work pertinent to resource appraisal are included here. No geophysical work was done. 


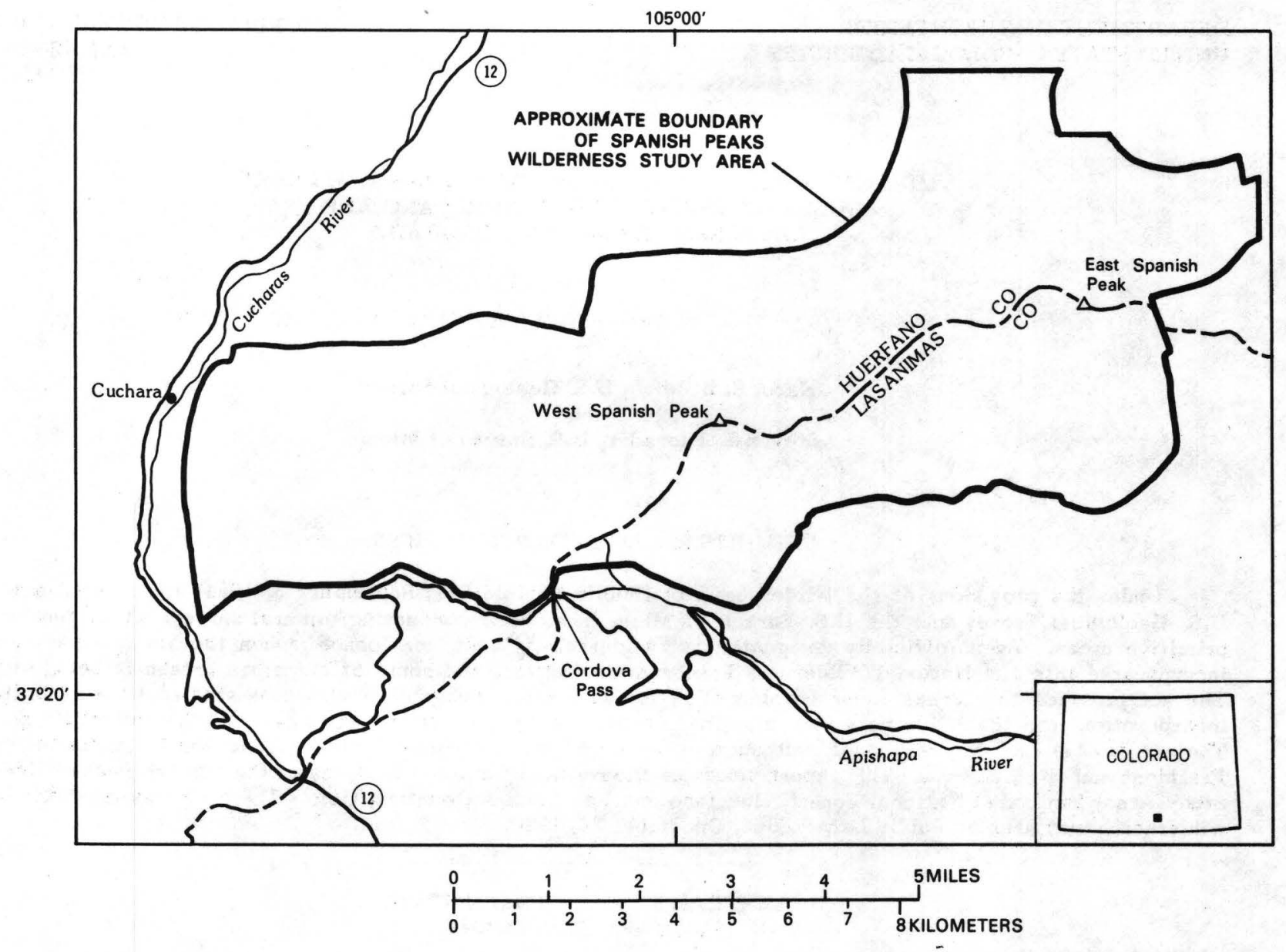

Figure 1.--Index map showing location of the Spanish Peaks Wilderness Study area, Huerfano and Las Animas Counties, Colo. 


\section{GEOLOGY}

Sedimentary rocks, Paleozoic to Tertiary in age, crop out near the Spanish Peaks. In the western part of the study area, these include sandstone, shale, limestone, siltstone, coal, and conglomerate from the Upper and Lower Cretaceous Dakota Sandstone upward through the Paleocene Poison Canyon Formation (Johnson, 1969). Most of the sedimentary rocks are included in the Eocene sandstone, siltstone, claystone, and shale of the undifferentiated Cuchara and Huerfano Formations (Robinson, 1966; Scott and Taylor, 1975).

The sedimentary rocks were invaded by the granite porphyry of East Spanish Peak 21.7 \pm 1.0 m.y. ago (Stormer, 1972); this event was closely followed by the intrusion of the compositionally similar granite of North, Middle, and South White Peaks. The core of East Spanish Peak was then intruded by porphyritic granodiorite. The syenodiorite of West Spanish Peak was emplaced 22.9 $92.0 \mathrm{~m} . \mathrm{y}$. ago (Smith, 1973) and is composed of several compositional varieties of syenodiorite. A large aureole of metamorphosed sedimentary rocks surrounds the body of syenodiorite. An impressive swarm of radial dikes, having trends related to stresses developed around the West Spanish Peak during magmatic activity, is found in the study area. Four radial dikes south of the peaks range in age from $22.4 \pm 3.1 \mathrm{~m} \cdot \mathrm{y}$. to $28.5 \pm 5.0 \mathrm{~m} \cdot \mathrm{y}$. (Smith, 1973). The compositions of the radial dikes vary from trachyte to augite-plagioclase lamprophyre; most are trachyandesite porphyries (Smith, 1977).

\section{MINES AND PROSPECTS}

\section{History and production}

All known workings in the study area are found in the zone of contact-metamorphosed sedimentary rocks surrounding the West Spanish Peak intrusive. Mineralized veinlets along a shear zone trending $\mathrm{N}$. $65^{\circ} \mathrm{E}$. have been worked in the Bulls Eye Mine on the north side of West Spanish Peak (fig. 2). Quartz veins bear argentiferous galena, tetrahedrite, chalcopyrite, and sphalerite, associated with siderite, calcite, and barite. Two mines on the eastern side and southeastern side of West Spanish Peak (here named "Mine 1" and "Mine 2," fig. 2), along with workings on several ridge tops, indicate areas of past mining activity. Vein material here is similiar to that found at the Bulls Eye Mine (Kluender, 1983).

The total production prior to 1908 from the mines on West Spanish Peak was $168 \mathrm{oz}$ of gold, 1,176 $\mathrm{oz}$ of silver, $92 \mathrm{lb}$ of copper, and $1,067 \mathrm{lb}$ of lead (Vanderwilt, 1947). Placer gold was reported by Hills (1901) from streams tributary to Wahatoya Creek and the Apishapa River. In 1932 and 1934, a few ounces of placer gold was produced from the north side of the study area. Four tons of lead-silver ore was shipped from the study area in 1934 and 1935 (Vanderwilt, 1947).

No workings are extensive, although at the Bulls Eye Mine the vein is traceable more than $0.5 \mathrm{mi}$ along strike and about 2,000 ft vertically above the main workings. In the Bulls Eye Mine adit accessible at the time of this study, the vein is $6-12$ in. wide; a vein sample taken at the face of the adit contained 0.026 $\mathrm{oz} /$ ton gold, $2.2 \mathrm{oz} /$ ton silver, 2.28 percent lead, and 4.40 percent zinc (Kluender, 1983). Minor amounts of copper and antimony were also found in a few of the samples.

\section{Mining and exploration activity}

No active mining or exploration efforts were underway in 1982. Records and patented mining claims on the Bulls Eye Mine, Mine 1, and along two ridges on West Spanish Peak are filed with the U.S. Bureau of Land Management. There has been recent drilling for petroleum or for carbon dioxide just south of the study area boundary, in the Apishapa River drainage. Most of the land within the study area is currently under oil and gas lease application.

\section{GEOCHEMICAL SURVEY}

To assist the assessment of the mineral resource potential of the study area, a geochemical survey was made, utilizing stream-sediment, panned-concentrate, and rock samples. Each sample-rock, stream sediment sieved to less-than- 80 mesh, and the nonmagnetic heavy-mineral fraction of the panned concentrate--was analyzed semiquantitatively for 31 elements using an optical emission spectrograph. Additional analyses for gold, bismuth, antimony, arsenic, zinc, and cadmium by atomic absorption and for uranium by fluorimetry were made on the rocks and stream sediments.

The majority of the geochemical anomalies were found in the vicinity of the old workings on West Spanish Peak. Table 1 describes the samples in the mineralized areas and lists their elements present in anomalous concentration-primarily lead, zinc, silver, copper, and minor gold. The rock samples that are not associated with the mines were collected from ridge tops in the northern and eastern parts of West Spanish Peak.

No gold was detected in the samples from tributaries to the Apishapa River and Wahatoya Creek, contrary to early reports by Hills (1901).

\section{ASSESSMENT OF MINERAL RESOURCE POTENTIAL}

The mineralized areas in the study area are associated with veins in the aureole of metamorphosed sedimentary rocks surrounding the West Spanish Peak intrusive. The veins are present near the contact with the intrusive mass, and many are associated with shear zones. The mineralized veinlets are few and low in grade; therefore, a moderate potential for small deposits of lead, zinc, copper, silver, and gold is assigned to those areas proximal to the old workings and to other mineralized or anomalous areas as indicated in figure 2.

Most of the study area lacks significant anomalies related to metallic deposits. Coal may underlie the study area, but only at a depth of several thousand feet; therefore, it is a resource that has little likelihood of development. The oil and gas potential likewise appears low because of the apparent lack of structural traps and the igneous activity in the area. 

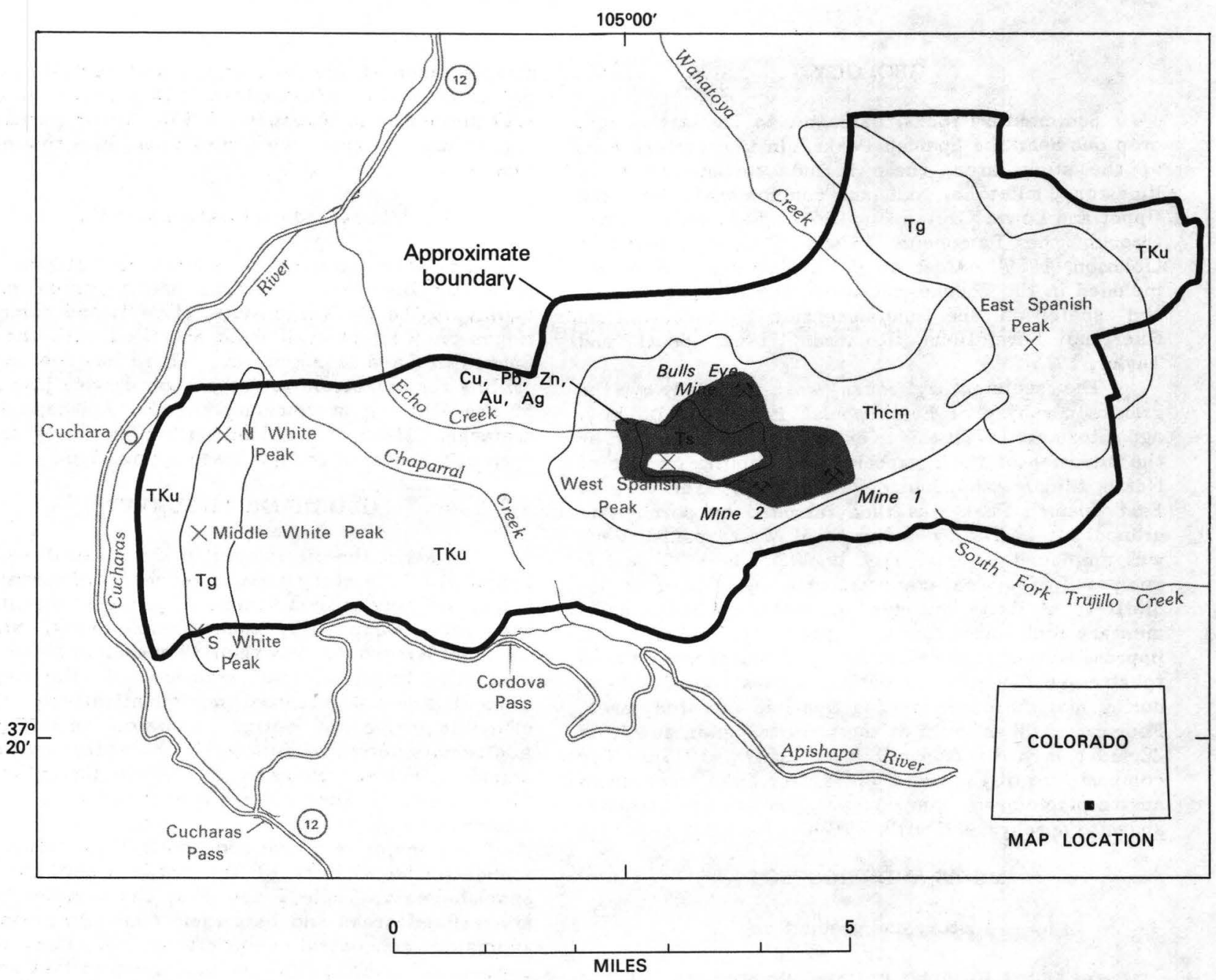

EXPLANATION

Area having moderate potential for small deposits of lead, zinc, copper, silver, and gold

$\mathrm{Cu} \quad$ Copper

Au Gold

\begin{tabular}{|c|c}
\hline Ts & Syenodiorite (Tertiary) \\
\cline { 1 - 1 } $\mathrm{Tg}$ & Granite, granodiorite (Tertiary) \\
\cline { 1 - 1 } $\mathrm{TKu}$ & $\begin{array}{c}\text { Undifferentiated sedimentary rocks } \\
\text { (Tertiary and Cretaceous) }\end{array}$
\end{tabular}

$\mathrm{Pb} \quad$ Lead

Thcm Metasedimentary rocks (Tertiary)

Ag Silver

Zn Zinc

Contact

Figure 2.--Map showing area of mineral resource potential in the Spanish Peaks Wilderness Study Area, Huerfano and Las Animas Counties, Colo. 
Table 1.--Chemically anomalous samples from West Spanish Peak

[Sample: SS, stream sediment; PC, panned concentrate; R, rock chip; X indicates anomalous concentration]

\begin{tabular}{|c|c|c|c|c|c|c|c|c|c|c|c|c|c|c|}
\hline $\begin{array}{l}\text { Sample } \\
\text { no. }\end{array}$ & $\mathrm{Ag}$ & $\mathrm{Bi}$ & $\mathrm{Cu}$ & Mo & $\mathrm{Ni}$ & $\mathrm{Pb}$ & $\mathrm{Zn}$ & As & $\mathrm{Au}$ & Cd & Co & $\mathrm{Sb}$ & $\mathrm{Sn}$ & Sample description \\
\hline SP-35-SS----- & $\mathrm{x}$ & $\mathrm{x}$ & $\mathrm{x}$ & $\mathrm{X}$ & & & $\mathrm{x}$ & $\mathrm{x}$ & $\mathrm{x}$ & $\mathrm{x}$ & & $\mathrm{x}$ & & $\begin{array}{l}\text { From drainage directly below Bulls Eye } \\
\text { Mine. }\end{array}$ \\
\hline SP-35-PC---- & & & & & & $\mathrm{x}$ & & & & & & & & Do. \\
\hline SP-37-SS---- & & & & & & $\mathrm{X}$ & $\mathrm{x}$ & $\mathrm{x}$ & & $\mathrm{X}$ & $\mathrm{X}$ & & & $\begin{array}{l}\text { From larger drainage basin farther below } \\
\text { Bulls Eye Mine. }\end{array}$ \\
\hline SP-37-PC----- & $\mathrm{x}$ & & $\mathrm{X}$ & & $\mathrm{x}$ & $\mathrm{x}$ & $\mathrm{x}$ & $\mathrm{X}$ & & & & & & Do. \\
\hline SP-28-R------ & $\mathrm{x}$ & $\mathrm{x}$ & $\mathrm{X}$ & & & $\mathrm{x}$ & $\mathrm{X}$ & $\mathrm{x}$ & $\mathrm{x}$ & $\mathrm{x}$ & & $\mathrm{x}$ & & $\begin{array}{l}\text { Channel sample of vein gouge at Bulls } \\
\text { Eye Mine. }\end{array}$ \\
\hline SP-146-R----- & $\mathrm{x}$ & $\mathrm{x}$ & & & & $\mathrm{x}$ & $\mathrm{x}$ & $\mathrm{x}$ & $\mathrm{x}$ & $\mathrm{x}$ & & $\mathrm{x}$ & & Gossan from prospect on ridge. \\
\hline SP-539B-R---- & $\mathrm{x}$ & $\mathrm{X}$ & & & & $\mathrm{X}$ & $\mathrm{X}$ & $\mathrm{x}$ & $\mathrm{x}$ & & & & & $\begin{array}{l}\text { From iron-stained shear zone in syeno- } \\
\text { diorite on ridge. }\end{array}$ \\
\hline SP-559-R----- & & & $\mathrm{x}$ & & & & & $\mathrm{x}$ & & & & & & $\begin{array}{l}\text { Iron-stained syenodiorite containing } \\
\text { sulfides, from ridge. }\end{array}$ \\
\hline SP-122-R----- & & & & $\mathrm{x}$ & & & & & & & & & & Iron-stained syenodiorite from ridge. \\
\hline SP-150-R----- & & & & & & & & & $\mathrm{x}$ & & & & & $\begin{array}{l}\text { Hornfels containing sulfides, from } \\
\text { ridge. }\end{array}$ \\
\hline SP-524-SS, PC- & & & & & & & $\mathrm{x}$ & & & & & & & From drainage below Mine 1 . \\
\hline SP-158-R----- & & & & & & $\mathrm{X}$ & & & & & & & $\mathrm{x}$ & $\begin{array}{l}\text { Iron-stained hornfels containing pyrite } \\
\text { boxwork, Mine } 1 \text {. }\end{array}$ \\
\hline SP-159-R----- & $\mathrm{x}$ & & $\mathrm{x}$ & & & & $\mathrm{x}$ & $\mathrm{x}$ & & $\mathrm{x}$ & & & & $\begin{array}{l}\text { Sulfide-rich syenodiorite from dump } \\
\text { below Mine } 1 \text {. }\end{array}$ \\
\hline SP-161-R----- & $\mathrm{X}$ & & $\mathrm{x}$ & & & $\mathrm{x}$ & $\mathrm{x}$ & $\mathrm{x}$ & & $\mathrm{x}$ & & & & $\begin{array}{l}\text { Iron-stained hornfels containing } \\
\text { sulfides, from dump below Mine } 1 \text {. }\end{array}$ \\
\hline SP-52-SS, PC-- & & & & & & & $\mathrm{x}$ & & & & & & & From drainage below Mine 2 . \\
\hline SP-162-R---- & $\mathrm{x}$ & $\mathrm{x}$ & $\mathrm{x}$ & & & $\mathrm{X}$ & $\mathrm{x}$ & $\mathrm{x}$ & & & & & & Channel sample from Mine 2 . \\
\hline SP-1 64-R----- & & $\mathrm{X}$ & $\mathrm{x}$ & & & & $\mathrm{x}$ & $\mathrm{X}$ & & & & & & $\begin{array}{l}\text { Iron-stained, sulfide-rich rock and } \\
\text { gossan from dump below Mine } 2 \text {. }\end{array}$ \\
\hline
\end{tabular}

\section{REFERENCES}

Budding, K. E., and Lawrence, V. A., 1983a, Geochemical maps of the Spanish Peaks Wilderness Study Area, Huerfano and Las Animas Counties, Colorado: U.S. Geological Survey Miscellaneous Field Studies Map MF-1542-B, scale 1:50,000.

$1983 \mathrm{~b}$, Reconnaissance geologic map of the Spanish Peaks Wilderness Study Area, Huerfano and Las Animas Counties, Colorado: U.S. Geological Survey Miscellaneous Field Studies Map MF-1542-A, scale 1:50,000.

Hills, R. C., 1901, Spanish Peaks folio: U.S. Geological Survey Geologic Atlas, Folio 71, 7 p.

Johnson, R. B., 1969, Geologic map of the Trinidad quadrangle, south-central Colorado: U.S. Geological Survey Miscellaneous Geologic Investigations Map I-558, scale 1:250,000.

Kluender, S. E., 1983, Mineral investigation of the Spanish Peaks Roadless Area, Huerfano and Las Animas Counties, Colorado: U.S. Bureau of Mines Open-File Report MLA 58-83.

Robinson, Peter, 1966, Fossil mammalia of the Huerfano Formation, Eocene, of Colorado: Yale University, Peabody Museum of Natural History Bulletin 21, 95 p.
Scott, G. R., and Taylor, R. B., 1975, Post-Paleocene Tertiary rocks and Quaternary volcanic ash of the Wet Mountain Valley, Colorado: U.S. Geological Survey Professional Paper 868, 15 p.

Smith, R. P., 1973, Age and emplacement structures of Spanish Peaks dikes, south-central Colorado [abs.]: Geological Society of America Abstracts with Programs, v. 5, p. 513-514.

1977, Geology of dikes in part of the Spanish Peaks dike system, south-central Colorado: Geological Society of America Map and Chart Series MC-22, 2 p. 1979, Early rift magmatism at Spanish Peaks, Colorado, in Riecker, R. E., ed., Rio Grande Rift-tectonics and magmatism: American Geophysical Union, Santa Fe, N.Mex., October 1978, p. 313-321.

Stormer, J. C., 1972, Ages and nature of volcanic activity on the southern high plains, New Mexico and Colorado: Geological Society of America Bulletin, v. 83, p. 2443-2448.

Vanderwilt, J. W., 1947, Metals, nonmetals, and fuels, Pt. 1, in Vanderwilt, J. W., Mineral resources of Colorado: Denver, Colo., Colorado Resources Board, p. 1-290. 